\title{
BRPKM
}

Buletin Riset Psikologi dan Kesehatan Mental

http://e-journal.unair.ac.id/index.php/BRPKM

e-ISSN: 2776-1851

ARTIKEL PENELITIAN

\section{Pengaruh Attitude toward Green Brand dan Green Brand Knowledge terhadap Green Purchase Intention pada Milenial}

\author{
DEA SHINTA SARASWATI \& ROSATYANI PUSPITA ADIATI*
}

Fakultas Psikologi Universitas Airlangga

\begin{abstract}
ABSTRAK
Penelitian ini bertujuan untuk mengetahui pengaruh attitude toward green product dan green brand knowledge terhadap green purchase intention pada generasi milenial. Penelitian ini melibatkan 125 partisipan dengan rentang usia 21-41 tahun. Teknik Analisa dalam penelitian ini menggunakan uji regresi dengan multiple regression dengan bantuan program Jamovi 1.6.23. Hasil analisis pada penelitian ini memiliki nilai signifikansi $(p)$ sebesar $<.001$ dengan koefisien regresi $\left(\mathrm{R}^{2}=0,454\right)$. Hasil tersebut menunjukkan bahwa attitude toward green brand dan green brand knowledge secara bersamaan dapat menjelaskan variasi green purchase intention sebesar $45.4 \%$. Nilai estimate kedua variable memiliki tanda positif, dimana berarti setiap kenaikan 1 skor attitude toward green brand akan menaikkan green purchase intention sebesar 0,108. Selanjutnya, kenaikan 1 skor green brand knowledge akan menaikkan green purchase intention sebesar 0,257.
\end{abstract}

Kata kunci: attitude toward green brand, green brand knowledge, green purchase intention

\begin{abstract}
This study aims to examine the effect of attitude toward green brand and green brand knowledge towards green purchase intention. The study involves 125 participants in age 21-41. The data analysis technique in this study using the regression with multiple regression with help of Jamovi 1.6.23 program. The result of the analysis in this study has significance value (p) of $<.001$ with a regression coefficient $\left(\mathrm{R}^{2}=0.454\right)$. These results indicate the attitude toward green brand and green brand knowledge can simultaneously explain the $45.4 \%$ variation in green purchase intention. The estimated value of the two variables has a positive sign, which means that every 1 increase in attitude toward green brand score will increase green purchase intention by 0.184 . Then, an increase of 1 green brand knowledge score will increase green purchase intention by 0.257 .
\end{abstract}

Keywords: attitude toward green brand, green brand knowledge, green purchase intention

Buletin Penelitian Psikologi dan Kesehatan Mental (BRPKM), 2021, Vol. 1(2), 1096-1104

*Alamat korespondensi: Fakultas Psikologi Universitas Airlangga, Kampus B Universitas Airlangga Jalan

Airlangga 4-6 Surabaya 60286. Surel: rosatyani.adiati@psikologi.unair.ac.id

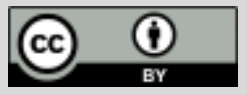

Naskah ini merupakan naskah dengan akses terbuka dibawah ketentuan the Creative Common Attribution License (CC-BY-4.0) (http://creativecommons.org/licenses/by/4.0), sehingga penggunaan, distribusi, reproduksi dalam media apapun atas artikel ini tidak dibatasi, selama sumber aslinya disitir dengan baik. 


\section{PENDAHULUAN}

Perubahan iklim sampai saat ini masih merupakan masalah yang belum bisa ditangani dengan baik, 64\% dari survei yang dilakukan oleh PBB menunjukkan bahwa masyarakat percaya dunia sudah berada dalam fase 'climate emergency' (Bellero, 2021). Dampak dari inkosistensi iklim sekitar inilah juga yang akhirnya memunculkan perilaku baru di antara para konsumen, dimana mereka mengintegrasikan aspek mengenai peduli lingkungan dengan gaya hidup mereka, hal inilah yang menyebabkan terjadinya perubahan pada perilaku konsumsi mereka (Do Paço dkk., 2014).

Perusahaan-perusahaan mulai menunjukkan sikap kepedulian mereka terhadap lingkungan, hal tersebut mereka tunjukkan dengan mengembangkan beberapa program yang memberikan solusi untuk masalah pada lingkingan, contoh perilaku yang bisa dikembangkan oleh suatu perusahaan adalah dengan menyediakan green product (Utami dkk., 2014). Green product dapat menjadi produk yang berinovasi dan juga membantu menghasilkan pengaruh yang cukup besar terhadap usaha melestarikan lingkungan dan merupakan kepedulian masyarakat terhadap pelestarian lingkungan (Adil, 2015).

Terdapat survei yang dilakukan oleh Nielsen pada tahun 2014, yaitu Global Survey of Corporate Social Responsibility yang menunjukkan bahwa 6 dari 10 konsumen di Indonesia bersedia mengeluarkan uang yang lebih untuk produk atau jasa yang memiliki dampak positif terhadap sosial dan juga lingkungan. Hal tersebut dianggap belum cukup dikarenakan kesadaran dari konsumen ini yang akan memiliki dampak jangka panjang dalam pembelian green product ini belum memuaskan (Indriani dkk., 2019). Perilaku pembelian dan juga green purchase intention di Indonesia masih rendah dikarenakan pengetahuan dan kesadaran konsumen Indonesia terhadap green product yang masih cukup rendah (Martana \& Ardani, 2018).

Kemauan yang kuat dalam melakukan suatu tingkah laku yang dimana salah satunya termasuk kegiatan membeli dapat dijelaskan menggunakan konsep intensi (Ajzen, 2005). Intensi ini sendiri merupakan sebuah aspek psikologis yang memiliki pengaruh yang cukup besar mengenai perilaku serta merupakan sumber motivasi dimana nantinya mempengaruhi apa yang akan dilakukan (Nisa, 2017). Sebelumnya, konsumen akan mengidentifikasi apa yang akan menjadi kebutuhannya lalu selanjutnya memikirkan dan mengumpulkan informasi mengenai produk apa yang akan memenuhi kebutuhannya. Setelah itu, konsumen yang telah mendapatkan informasi tersebut akan dimasukkan ke dalam memori jangka panjangnya (Efendi \& Baidun, 2015).

Purchase intention seorang consume akan dipengaruhi oleh beberapa faktor, diantaranya adalah kepercayaan (trust), kemudahan (easy of use), produk (product), harga (price), dan promosi (promotion) (Nisa, 2017). Untuk green purchase intention dampak terhadap lingkungan merupakan hal yang dirasa penting bagi konsumen, hal itu yang akan meningkatkan daya beli pada green product (Junaedi, 2005).

Green product yang telah dibeli oleh seorang konsumen akan berhasil dikarenakan nilai-nilai dari atribut yang terdapat pada produk tersebut, hal ini yang menunjukkan bahwa atribut dari green product itu akan berkontribusi untuk konsumen akan melakukan pembelian green product itu kembali (Situmorang dkk., 2021). Konsumen yang telah memiliki pengetahuan terkait lingkungan dan juga memiliki pengalaman positif terkait pembelian green product di masa lalunya akan memiliki kecenderungan yang tinggi untuk menunjukkan green purchase intention yang kuat (Suki, 2016). 
Generasi Milenial merupakan generasi yang disebut sebagai generasi yang paling peduli terhadap lingkungan. Generasi ini dilihat sebagai generasi yang paling berorientasi pada konsumsi ramah lingkungan dibandingan dengan generasi lainnya (Sullivan \& Heitmeyer, 2008). Generasi ini juga merupakan generasi yang lebih teredukasi, hal ini menunjukkan bahwa konsumen yang lebih teredukasi akan meningkatkan rasa peduli mereka terhadap efek jangka panjang dari produk yang mereka beli pada kesehatan, komunitas, dan juga lingkungan (Lu dkk., 2013). Akan tetapi, lebih dari $50 \%$ diantara milenial pada survei yang dilakukan Ad Age pada tahun kepada milenial mengenai green brand, mereka tidak dapat menyebutkan satupun brand yang secara aktif mendukung gerakan ramah lingkungan. Mereka mengklaim bahwa mereka ingin mendukung green product akan tetapi mereka merasa kesulitan menemukannya (Lupberger, 2017).

Terdapat penelitian terdahulu yang juga mendukung penelitian ini. Pada penelitian sebelumnya ditemukan bahwa attitude toward green brand (AGB) dan green brand knowledge (GBK) memiliki pengaruh positif dan juga hasil yang signifikan terhadap green purchase intention (GPI) (Suki, 2016), hal itu tidak sejalan dengan hasil dari penelitian sebelumnya yang menunjukkan bahwa AGB tidak memiliki pengaruh terhadap GPI (Chin dkk., 2018). Selain itu, GBK juga ditemukan tidak memiliki pengaruh terhadap GPI (Wahyuningtias \& Artanti, 2020).

Dengan didasari pemaparan terkait masalah diatas, maka penulis memiliki ketertarikan untuk meneliti lebih lanjut mengenai apakah terdapat pengaruh antara AGB dan GBK terhadap green purchase intention pada generasi milenial.

Tujuan dilakukanya penelitian untuk mengetahui apakah terdapat pengaruh antara attitude toward green brand dan juga green brand knowledge terhadap green purchase intention pada generasi milenial. Adapun pertanyaan penelitian ini adalah $\left(\mathrm{H}_{1}\right)$ attitude toward green brand berpengaruh terhadap green purchase intention pada generasi milenial, $\left(\mathrm{H}_{2}\right)$ green brand knowledge berpengaruh terhadap green purchase intention pada generasi milenial, $\left(\mathrm{H}_{3}\right)$ attitude toward green brand dan green brand knowledge secara bersamaan berpengaruh terhadap green purchase intention pada generasi milenial dan $\left(\mathrm{H}_{0}\right)$ tidak terdapat pengaruh yang signifikan dari attitude toward green brand, dan green brand knowledge terhadap green purchase intention pada generasi milenial.

\section{Desain Penelitian}

\section{METODE}

Penelitian ini mengunakan tipe penelitian dengan pendekatan kuantitatif. Penelitian kuantitatif memiliki terminologi khusus dan juga serangkaian teknik yang tujuannya adalah untuk menangkap dengan tepat mengenai rincian dunia sosial empiris dan juga mengekspresikan apa yang ditemukan dalam angka (Neuman, 2014). Jenis penelitian yang dilakukan adalah penelitian eksplanatori, dimana penelitian ini memiliki tujuan untuk menjelaskan pengaruh atau hubungan antar variabel-variabel penelitian yang telah dirancang sebelumnya pada penelitian ini (Neuman, 2007). Penelitian ini dirancang penulis dengan menggunakan tiga variabel yang terdiri atas dua variabel independen yaitu attitude toward green brand sebagai $\mathrm{X}_{1}$ dan green brand knowledge sebagai $\mathrm{X}_{2}$, lalu terdapat satu variabel dependen (Y) yaitu green purchase intention. Tiga variabel ini digunakan untuk mengentahui apakah terdapat pengaruh antara attitude toward green brand dan green brand knowledge terhadap green purchase intention pada generasi milenial. 


\section{Partisipan}

Teknik sampling pada penelitian ini menggunakan purposive sampling, hal itu menunjukkan bahwa pengambilan sampel dilakukan berdasarkan suatu kriteria tertentu sehingga siapa saja yang termasuk dalam kriteria yang sudah ditentukan sebelumnya dapat mengisi kuisioner yang disebarkan oleh peneliti (Neuman, 2014). Kriteria yang telah ditentukan untuk partisipan yang sesuai dalam penelitian ini yaitu, Warga Negara Indonesia yang berusia 21-41 tahun dan pernah membeli produk ramah lingkungan sebelumnya. Dalam penelitian ini, sebelumnya peneliti menggunakan analisis $G^{*}$ Power dengan perangkat $G^{*}$ Power 3.1.9.7 untuk menentukkan jumlah sampel. Hal ini dilakukan guna menyesuaikan nilai power yang ingin didapatkan untuk memperkuat hasil penelitian (Navarro \& Foxcroft, 2018). A priori power analysis dengan menggunakan jenis tes linear multiple regression: fixed model dan $R^{2}$ deviation from zero. Analis tersebut dilakukan sehingga mendapatkan informasi untuk mendeteksi effect size sebesar 0.15 dengan statistical power $95 \%$ dan alpha $5 \%$ dengan dua prediktor yang digunakan, maka dibutuhkan sampel minimum 107 partisipan. Lalu, sebelum partisipan mengisi tiga instrumen yang disediakan oleh penulis, partisipan harus terlebih dahulu mengisi informed consent pada bagian pertama dan kemudian mengisi tiga instrumen alat ukur pada bagian selanjutnya.

\section{Pengukuran}

Alat ukur yang digunakan dalam penelitian ini untuk variabel $\mathrm{X}_{1}$ adalah alat ukur attitude toward green brand yang dikembangkan dari dimensi oleh Hartmann, dkk (2005) yang terdiri dari 10 item dengan 5 pilihan jawaban ( 1 = "sangat tidak setuju, 5 = "sangat setuju"). Selanjutnya, alat ukur yang digunakan untuk variabel $\mathrm{X}_{2}$ adalah alat ukur green brand knowledge yang dikembangkan dari dimensi oleh Keller (1993) yang terdiri dari 9 item dengan 5 pilihan jawaban ( 1 = "sangat tidak setuju, 5 = "sangat setuju"). Lalu untuk variabel Y, alat ukur yang digunakan merupakan alat ukur green purchase intention dikembangkan dari definisi oleh Suki (2016) yang terdiri dari 5 item dengan 5 pilihan jawaban $(1=$ "sangat tidak setuju, 5 = "sangat setuju"). Teknik validitas pada ketiga alat ukur pada penelitian ini menggunakan pendekatan content validity yaitu, expert judgement yang dilakukan dengan bantuan tiga professional judgement.

Reliabilitas dari ketiga alat ukur diatas menggunakan teknik Cronbach's apha. Hasil uji reliabilitas pada alat ukur attitude toward green brand adalah $\alpha=0.822$, pada alat ukur green brand knowledge adalah $\alpha=0,800$, dan pada alat ukur green purchase intention adalah $\alpha=0.855$. Dari nilai-nilai tersebut, menunjukkan bahwa ketiga variabel dalam penelitian ini dapat dikatakan reliabel karena ketiganya tergolong memiliki tingkat reliabilitas yang tinggi.

\section{Analisis Data}

Dalam penelitian ini, proses analisis yang dilakukan adalah dengan menggunakan bantuan dari program statistik yaitu Jamovi yang akan digunakan untuk mengetahui apakah hipotesis yang telah diusulkan diterima atau ditolak. Selanjutnya, untuk mengidentifikasi adanya pengaruh dari attitude toward green brand dan green brand knowledge terhadap green purchase intention akan dilakukan uji regresi dengan simple linear regression dan multiple regression. Model ini akan mengungkap persamaan garis yang diperlukan untuk memprediksi nilai variabel outcome atau Y ketika nilai prediktor atau X diketahui (Navarro \& Foxcroft, 2018). Namun sebelum melakukan uji regresi tersebut, terdapat beberapa asumsi yang harus terpenuhi terlebih dahulu dan dapat diketahui melalu uji statistik lainnya terlebih dahulu. Asumsi yang harus terpenuhi terlebih dahulu adalah uji normalitas, uji linearitas, uji multikolinearitas,

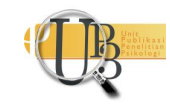


analisis residual, uji homoskedasdisitas, dan juga deteksi outlier yang berpotensi mengganggu hasil penelitian. Semua prosedur analisis yang dilakukan dalam penelitian ini akan menggunakan bantuan dari program statistic yaitu program Jamovi 1.6.23

\section{HASIL PENELITIAN}

\section{Uji Deskriptif}

Hasil uji deskriptif pada 125 partisipan dengan presentase 21,6\% laki-laki dan 78,4\% perempuan menunjukkan bahwa variabel Attitude toward Green Brand memiliki nilai $(M=40,7 ; S D=5,15$; $M i n=25$; $M a x=50)$. Pada variabel Green Brand Knowledge memiliki nilai $(M=36,9 ; S D=4,82 ; M i n=22 ; \operatorname{Max}=45)$. Selanjutnya pada variabel Green Purchase Intention memiliki nilai $(M=22,3$; SD=2,51; Min=16; $M a x=25)$.

\section{Uji Hipotesis}

Setelah uji asumsi telah terpenuhi, selanjutnya penulis melakukan uji linearitas guna menguji bahwa terdapat hubungan linear antara variabel independen dan juga variabel dependen. Selanjutnya dalam penelitian ini, penulis menggunakan korelasi spearman untuk melakukan uji linearitas. Berdasarkan hasil uji korelasi diketahui bahwa AGB berkorelasi positif dan cenderung kuat $(\mathrm{r}(125)=0,571 ; p<0.001)$ dengan GPI. Lalu, berdasarkan hasil uji korelasi diketahui pula bahwa GBK berkolasi positif dan cenderung kuat $(\mathrm{r}(125)=0,690 ; p<0.001)$ dengan GPI.

Uji asumsi dan juga uji linearitas terpenuhi dan yang terakhir adalah dengan melakukan uji analisis regresi Linear Berganda. Data yang diperoleh pada penelitian ini menunjukan $(\mathrm{F}(2,122)=50.8$, nilai $p$ $=<.001)$. Nilai koefisien regresi $\left(\mathrm{R}^{2}\right)$ sebesar 0.454, nilai tersebut memiliki makna bahwa AGB dan GBK secara bersamaan dapat menjelaskan variasi GPI sebesar 45.5\%. Sedangkan sisanya dijelaskan oleh variabel lain yang tidak dibahas dalam penelitian ini. Didapatkan persamaan garis regresi linear sebagai berikut: $\mathrm{Y}^{\prime}=8.420+(0,108) \mathrm{X} 1+(0,257) \mathrm{X} 2+\mathrm{e}$. Melalui persamaan garis tersebut dapat disimpulkan bahwa variabel attitude toward green brand $\left(\mathrm{B}=0,108 \mathrm{CI}_{95}=[0,0124 ; 0,204], \mathrm{SE}=0,0483, t=2,24\right.$ nilai $p<0.05)$, green brand knowledge knowledge $\left(\mathrm{B}=0.257 \mathrm{CI}_{95}=[0,1543 ; 0,359], \mathrm{SE}=0,0517, t=4,97\right.$ nilai $p<0,001)$ merupakan prediktor yang mampu menjelaskan green purchase intention.

\section{DISKUSI}

Hasil penelitian kali ini menunjukkan bahwa attitude toward green brand berpengaruh terhadap green purchase intention pada generasi milenial dan menunjukkan arah yang positif. Hasil penelitian ini didukung oleh penelitian sebelumnya yang juga menemukan bahwa attitude toward green brand memiliki dampak positif terhadap green purchase intention dengan fokus produk yang digunakan adalah personal care dan juga produk kosmetik di Jakarta (Aulina \& Yuliati, 2017). Selain itu, pengaruh positif dari AGB juga berpengaruh positif terhadap GPI dengan fokus green consumer di Malaysia (Suki, 2016). Temuan-temuan pada penelitian sebelumnya inilah yang pada akhirnya memberi asumsi bahwa memang terdapat pengaruh dari AGB terhadap GPI. Hal ini menunjukkan bahwa dengan memiliki sikap positif terhadap green product maka akan memberikan pengaruh yang signifikan terhadap GPI pada generasi milenial. Perasaan dari konsumen dan juga sikap positif yang dimiliki konsumen merupakan dampak yang mendasar yang dapat membentuk sikap konsumen sehingga mempengaruhi niat mereka untuk membeli suatu produk (Schiffman \& Wisenblit, 2014). Kepercayaan yang dipegang oleh seoarang individu terhadap sebuah green brand yang dimana produk tersebut merupakan produk yang lebih

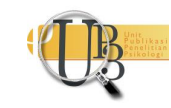


sehat dan juga dapat menjanjikan perlindungan terhadap lingkungan yang lebih baik, lalu usaha yang dilakukan oleh tiap perusahaan dalam menyampaikan atribut ramah lingkungan mereka terhadap konsumen ini yang akan membantu konsumen dalam membuat keputusan diantara brand-brand alternatif (Aulina \& Yuliati, 2017). Konsumen dengan sikap positif terhadap brand-brand tertentu maka konsumen tersebut akan memiliki intensi pembelian pada produk dari brand tersebut (Teng, 2009). Sikap positif terhadap suatu brand ini juga menunjukkan bahwa konsumen tersebut memiliki kesadaran lingkungan yang tinggi dan juga seringkali menikmati penggunaan brand ramah lingkungan, sehingga secara mental mereka mulai melihat brand tersebut sebagai aspek utama dari diri mereka sendiri (Suki, 2016).

Selanjutnya, ditemukan pula green brand knowledge berpengaruh terhadap green purchase intention. Temuan dari penelitian ini menunjukkan bahwa adanya pengaruh signifikan yang diberikan oleh GBK terhadap GPI dengan arah yang positif. Hasil ini sejalan dengan penelitian sebelumnya dimana GBK memiliki dampak positif terhadap GPI dengan fokus green consumer di Malaysia (Suki, 2016). Sejalan juga dengan penelitian yang menemukan bahwa GBK memiliki dampak positif terhadap GPI dengan fokus produk yang digunakan adalah personal care dan juga produk kosmetik di Jakarta (Aulina \& Yuliati, 2017). Temuan-temuan pada penelitian sebelumnya inilah yang pada akhirnya memberi asumsi bahwa memang terdapat pengaruh dari GBK terhadap GPI. Hal ini menunjukkan bahwa dengan memiliki pengetahuan terkait green product maka akan memberikan pengaruh yang signifikan terhadap GPI pada generasi milenial.

Pengetahuan akan green brand itu sendiri akan membuat konsumen lebih sadar akan kualitas dari green product itu sendiri. Dengan ditingkatkannya usaha mengomunikasikan mengenai green product itu sendiri nantinya akan meningkatkan kesadaran dan juga minat konsumen tehadap brand tersebut (Aulina \& Yuliati, 2017). Konsumen yang akan berekspektasi untuk menadapatkan informasi yang reliable mengenai isu lingkungan saat ini guna meningkatkan green brand knowledge dan juga memfasilitasi pembelian green product. Selanjutnya, konsumen yang telah memiliki wawasan mengenai lingkungan yang lebih tinggi juga akan cenderung melakukan kepedulian lingkungan yang kuat, sehingga hal ini juga dapat dilihat melalui sikap konsumen yang akan lebih memilih green product dibandingkan dengan produk yang lainnya (Suki, 2016). Apabila terdapat lebih banyak ketersediaan porduk ramah lingkungan ini sendiri dapat menciptakan pengetahuan yang lebih baik bagi individu dan juga membantu mereka dalam mengidentifikasi green product yang ada (Sreen dkk., 2018). Lalu, konsumen yang memiliki pengetahuan green brand yang tinggi juga akan meningkatkan perhatian khusus akan perlindungan lingkungan dalam memilih produk-produk yang akan dimiliki, yang berarti konsumen yang memiliki pengetahuan yang baik mengenai green brand tersebut akan mengetahui kebaikan-kebaikan yang akan ia dapatkan apabila membeli produk tersebut, dan juga akan meningkatkan perhatian lebih terhadap lingkungan disekitarnya (Suki, 2016).

Green solution pada tahun 2007 menunjukkan bahwa milenial merupakan generasi yang peduli terhadap lingkungan dan sebagai hasil dari hal tersebut adalah sebagian besar milenial memiliki sikap yang positif terhadap green product dan juga bersedia untuk membayar lebih untuk layanan, produk, atau green brand. Tantangan bagi para penyedia green product untuk dapat mengkomunikasikan pesan terkait lingkungan kepada konsumennya, dan dengan melihat bahwa milenial merupakan aspek penting terhadap lingkungan, karakteristik ramah lingkungan dari setiap produk merupakan faktor yang cukup penting guna membangun loyalitas dari konsumen (Lu dkk., 2013). Apabila milenial ini dapat diyakinkan dengan baik mengenai green product dan dapat mengubah pola pembelian dari para milenial, salah satunya adalah dengan membuat mereka melaksanakan intensi mereka menjadi pembelian, maka akan terdapat dampak yang sangat besar sekali dikarenakan kekuatan pembelian milenial yang luar biasa besar (Wiranto \& Adialita, 2020). 


\section{SIMPULAN}

Berdasarkan serangkaian proses pengujian dan analisis yang telah dilakukan, diketahui bahwa terdapat pengaruh attitude toward green brand terhadap green purchase intention pada generasi milenial, terdapat pengaruh green brand knowledge terhadap green purchase intention pada generasi milenial, dan secara bersamaan attitude toward green brand dan green brand knowledge memiliki pengaruh yang signifikan terhadap green purchase intention pada generasi milenial. Arah pengaruh dari kedua variable prediktor sama-sama menunjukkan arah positif, sehingga dapat disimpulkan bahwa semakin tinggi attitude toward green brand dan green brand knowledge yang dimiliki oleh individu dapat menyebabkan semakin tinggi pula green purchase intention yang dimiliki.

\section{UCAPAN TERIMAKASIH}

Penulis sangat ingin mengucapkan terima kasih yang setulus-tulusnya dan sedalam-dalamnya terhadap pihak-pihak yang turut serta membantu dalam proses penulisan naskah ini. Terima kasih juga saya tujukan kepada Rosatyani Puspita Adiati, M.Psi., Psikolog, selaku dosen pembimbing penulis, kepada seluruh jajaran dosen pengajar dan juga staf yang turut membantu penelitian ini dari Fakultas Psikologi Universitas Airlangga, juga kepada seluruh partisipan penelitian ini, dan juga kepada seluruh pihak yang membantu yang tidak dapat disebutkan seluruhnya.

\section{DEKLARASI POTENSI TERJADINYA KONFLIK KEPENTINGAN}

Dea Shinta Saraswati dan Rosatyani Puspita Adiati tidak bekerja, menjadi konsultan, memiliki saham, atau menerima dana dari perusahaan atau organisasi manapun yang mungkin akan mengambil untung dari diterbitkannya naskah ini.

\section{PUSTAKA ACUAN}

Adil, A. (2015). Adil, A. (2015). Pengaruh pengetahuan tentang lingkungan, sikap pada lingkungan, dan norma subjektif terhadap niat pembelian green product. Jurnal Ekonomi Dan Kewirausahaan, 15(April), 122-128.

Ajzen, I. (2005). Attitudes, Personallity and Behavior. In International Journal of Strategic Innovative Marketing (2nd ed., Vol. 3). McGraw-Hill Education.

Aulina, L., \& Yuliati, E. (2017). The Effects of Green Brand Positioning, Green Brand Knowledge, and Attitude towards Green Brand on Green Products Purchase Intention. 36(Icbmr), 548-557. https://doi.org/10.2991/icbmr-17.2017.50

Bellero, S. (2021). Climate change is a "global emergency", people say in biggest ever climate poll. UN News.

http://www.un.org/news/story.asp?NewsID=18627\&utm_medium=referral\&utm_source=pulse news\#.UKuopuTKfa8

Chin, J., Jiang, B. C., Mufidah, I., Persada, S. F., \& Noer, B. A. (2018). The investigation of consumers' behavior intention in using green skincare products: A pro- environmental behavior model

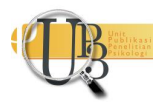


approach. Sustainability (Switzerland), 10(11). https://doi.org/10.3390/su10113922

Do Paço, A., Alves, H., Shiel, C., \& Filho, W. L.. (2014). An analysis of the measurement of the construct "buying behaviour" in green marketing. In Journal of Integrative Environmental Sciences (Vol. 11, Issue 1, pp. 55-69). Taylor \& Francis. https://doi.org/10.1080/1943815X.2014.894082

Efendi, J., \& Baidun, A. (2015). Faktor-Faktor Psikologis yang Mempengaruhi Intensi Membeli Produk Fashion Tiruan. Tazkiya Journal of Psychology, 20(2), 287-303.

Hartmann, P., Ibanez, V. A., \& Sainz, F. J. (2005). Green branding effects on attitude: functional versus emotional positioning strategies. Marketing Intelligence \& Planning, 23(1), 9-29.

Indriani, I. A. D., Rahayu, M., \& Hadiwidjojo, D. (2019). The Influence of Environmental Knowledge on Green Purchase Intention the Role of Attitude as Mediating Variable. International Journal of $\begin{array}{llll}\text { Multicultural and } \quad \text { Multireligious } & \text { Understanding, }\end{array}$ https://doi.org/10.18415/ijmmu.v6i2.706

Junaedi, M. F. S. (2005). Pengaruh Kesadaran Lingkungan Pada Niat Beli Produk Hijau : Studi Perilaku Konsumen Berwawasan Lingkungan. Benefit: Jurnal Manajemen Dan Bisnis, 9(2), 189-201.

Keller, K. L. (1993). Conceptualizing, measuring, and managing customer-based brand equity. Journal of Marketing, 57(1), 1-22.

Lu, L., Bock, D., \& Joseph, M. (2013). Green marketing: What the Millennials buy. Journal of Business Strategy, 34(6), 3-10. https://doi.org/10.1108/JBS-05-2013-0036

Lupberger, R. (2017). 5 Reasons Why Millennials Don't Buy Green Brands. SocapDigital. https://socapglobal.com/2017/06/5-reasons-millennials-dont-buy-green-brands-better-wayreach/

Martana, I., \& Ardani, I. (2018). Peran Sikap Dalam Memediasi Pengaruh Kesadaran Lingkungan Terhadap Niat Beli Ulang Produk Minuman Kemasan Hijau. E-Jurnal Manajemen Universitas Udayana, 7(10), 5478. https://doi.org/10.24843/ejmunud.2018.v07.i10.p10

Navarro, D. J., \& Foxcroft, D. R. (2018). Learning statistics with jamovi: a tutorial for psychology students and other beginners. Danielle J. Navarro and David R. Foxcroft. https://doi.org/10.24384/HGC37P15

Neuman, W. L. (2007). Basic of Social Research. Pearson Education, Inc.

Neuman, W. L. (2014). Social Research Methods: Qualitative and Quantitative Approaches (7th Editio). Pearson Education, Inc.

Nisa, L. N.N. (2017). Hubungan Online Trust dengan Purchase Intention pada Konsumen di Media Instagram. Universitas Negeri Semarang.

Schiffman, L. G., \& Wisenblit, J. (2014). Consumer Behavior. Pearson Education, Inc.

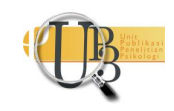


Situmorang, T. P., Indriani, F., Simatupang, R. A., \& Soesanto, H. (2021). Brand Positioning and Repurchase Intention: The Effect of Attitude Toward Green Brand. Journal of Asian Finance, Economics and Business, 8(4), 491-499. https://doi.org/10.13106/jafeb.2021.vol8.no4.0491

Sreen, N., Purbey, S., \& Sadarangani, P. (2018). Impact of culture, behavior and gender on green purchase intention. Journal of Retailing and Consumer Services, 41(July 2017), 177-189. https://doi.org/10.1016/j.jretconser.2017.12.002

Suki, N. M. (2016). Green product purchase intention: impact of green brands, attitude, and knowledge. British Food Journal, 118(12), 2893-2910. https://doi.org/10.1108/BFJ-06-2016-0295

Sullivan, P., \& Heitmeyer, J. (2008). Looking at Gen Y shopping preferences and intentions: Exploring the role of experience and apparel involvement. International Journal of Consumer Studies, 285-296.

Teng, L. (2009). A Comparison of Two Types of Price Discounts in Shifting Consumers' Attitude and Purchase Intention. Journal of Business Research, 62(1), 14-21.

Utami, R. D., Gunarsih, T., \& Aryanti, T. (2014). Pengaruh Pengetahuan, Kepedulian dan Sikap pada Lingkungan terhadap Minat Pembelian Produk Hijau. Media Trend, 9(2), 151-161.

Wahyuningtias, L., \& Artanti, Y. (2020). Pengaruh Green Brand Positioning dan Green Brand Knowledge Terhadap Green Purchase Intention Melalui. Jurnal Muara Ilmu Ekonomi Dan Bisnis, 4(2), 320-329.

Wiranto, A., \& Adialita, T. (2020). Pengaruh Green Product Knowledge, Green Trust, dan Perceived Price terhadap Green Purchase Intention Konsumen AMDK Merk Aqua dengan Botol 100\% Recycled. Jurnal Administrasi Bisnis, 16(2), 174-184. 